Василь Осьодло, доктор психологічних наук, професор ORCID ID 0000-0003-2893-4721

Тетяна Ворона ORCID ID 0000000155443341 Анатолій Пелих, кандидат наук з державного управління

ORCID ID 0000-0001-8720-9816 Національний університет оборони України імені Івана Черняховського

\title{
ВИЩА ВІЙСЬКОВА ОСВІТА УКРАЇНИ У КОНТЕКСТІ ІНФОРМАЦІЙНОГО СУСПІЛЬСТВА
}

В статті проведено аналіз сучасних тенденцій щзодо ролі інформаційного суспільства в прочесі підготовки особистості офіщера в системі вищої військової освіти України. Розкрито основні стратегічні иілі та завдання розвитку інформаційного суспільства в освітній сфері Украӥни. Окреслено основні тенденції розвитку системи вищої військової освіти Украӥни в умовах ведення гібридної війни. Запропоновано основні иляхи реалізації прикладних завдань системи вищої військової освіти України в інформаційному суспільстві в організаційній, науково-методичній та управлінській площині.

Ключові слова: інформащчійне суспільство; вища військова освіта; якість освіти; військово-професійна діяльність.

Постановка проблеми в загальному вигляді. У сучасних умовах інформаційне суспільство представляє якісно новий етап соціотехнологічної еволюції суспільства, що формувалося й продовжує розвиватися в результаті провідних тенденцій попереднього його соціально-економічного розвитку. Таке суспільство передбачає суттєве, а подекуди і вирішальне збільшення ролі інформації і знань у всіх сферах суспільного та людського буття, а також формування i споживання інформаційних ресурсів за допомогою інформаційно-комунікаційних технологій (далі - ІКТ). В умовах сьогодення характер дій цих технологій набуває глобального характеру. У розвинених країнах світу сфера IКТ виступає підвалиною соціального, економічного та політичного благополуччя населення, однією з провідних умов економічного розвитку.

Аналіз останніх досліджень і публікацій. Починаючи 3 90-х років $\mathrm{XX}$ ст. розвиток інформаційного суспільства стає пріоритетним напрямом державної політики в провідних країнах світу [2; 5]. У грудні 2003 року проблема створення глобального інформаційного суспільства вперше актуалізується на вищому міждержавному рівні у межах проведення Першої стадії Всесвітнього Саміту з питань інформаційного суспільства. В ході роботи саміту лідери 161 держави світу підписали два стратегічні документи “Декларацію принципів" і "План дій”, які визначили напрями подальшого розвитку інформаційного суспільства на всіх рівнях, а також окреслили 
необхідність розроблення і реалізації національних стратегій його розвитку в окремо взятій країні.

3 початком ведення антитерористичної операції проблема формування потужного інформаційного простору в усіх сферах українського суспільства, у тому числі й в системі вищої військової освіти набула особливої актуальності й потребує нагального вирішення.

Мета статті спрямована на 3'ясування впливу інформаційного суспільства на систему вищої військової освіти України.

Виклад основного матеріалу дослідження. Проблема інформаційного суспільства, зокрема, роль і місце людини в процесах глобалізації та інформаційних взаємодіях, специфіка розвитку інформаційного суспільства проаналізовані в багатьох працях вітчизняних та зарубіжних філософів, політологів, соціологів та інших вчених.

Проте теоретичне обгрунтування розвитку інформаційного суспільства значно відстає від практичного використання ІКТ. Таким чином, $є$ доцільним розглянути інформаційний розвиток 3 позиції соціального, політичного i філософського аналізу. Створення наукової концепції, здатної синтезувати загальні проблеми інформаційного суспільства, а також перспективи розвитку інформаційного простору України, складає надзвичайно актуальне теоретичне завдання, вирішення якого дозволить організаторам військової освіти усвідомити свою роль і місце в нових умовах, обгрунтувати стратегію інформаційного розвитку нашої країни, з'ясувати особливості інформаційних процесів у ВВНЗ, а також успішно вирішувати суто практичні завдання щодо інформатизації підготовки військових фахівців.

В інформаційному суспільстві головним джерелом існування і розвитку особи та всього суспільства, основним ресурсом функціонування і рушійною силою прогресивних перетворень стають знання та інформація, які накопичило і продовжує продукувати та накопичувати людство й які будуть ефективно використовуватись практично усіма підсистемами суспільства, переважною більшістю його членів для розв'язання своїх повсякденних i професійних завдань. В умовах гібридної війни розв'язаної Російською Федерацією проти України інформаційне суспільство перетворюється в таке глобальне суспільство, в якому обмін інформацією не обмежується жодними часовими, просторовими чи політичними кордонами [4]. Це в свою чергу, передбачає різке зростання ролі знань та інформації, які стали важливим стратегічним ресурсом як всього суспільства, Збройних Сил України так i окремої особи.

Виходячи з вищезазначеного широкий доступ громадян до інформації, освіти, культурних надбань, сприятливі умови для кожного щодо створення інформації і знань, доступ до них, користування й обмін ними, створення нових можливостей роботи й спілкування завдяки бурхливому розвитку і широкомасштабному впровадженню ІТК у всі сфери життєдіяльності як окремої людини, так і суспільства $\epsilon$ запорукою успішного майбутнього України. 
До основних стратегічних иілій розвитку інформаційного суспільства в освітній сфері в Україні прийнято відносити: забезпечення комп'ютерної та інформаційної грамотності населення, насамперед шляхом створення системи освіти, орієнтованої на використання сучасних ІКТ у формуванні гармонійно розвиненої особистості; створення загальнодержавних інформаційних систем, насамперед у сферах охорони здоров'я, освіти, науки, культури, охорони довкілля; захист інформаційних прав громадян, насамперед щодо доступності інформації, захисту інформації про особу, підтримки демократичних інститутів та мінімізації ризику "інформаційної нерівності"; покращення стану інформаційної безпеки в умовах використання сучасних ITК $[3 ; 6]$.

Досягнення окреслених цілей сприятиме розв'язуванню ключових завдань щодо забезпечення якісної сучасної освіти. Інформатизація українського суспільства передбачає випереджальну інформатизацію всіх рівнів освіти, у тому числі й вищу військову, де, в основному, формується кадровий фундамент самої інформатизації військової сфери, закладаються майбутне для Збройних Сил України та обороноздатності держави в цілому [2].

Вища військова освіта інформаційного суспільства істотно відрізняється від освіти індустріальної епохи своїми цілями, методами, технологіями і можливостями освітньої діяльності, а також результатами. У зв'язку з цим перед нею виникло ряд складних взаємопов'язаних і взаємозумовлених утилітарних і стратегічних завдань:

1) вона має осучаснюватися на основі сучасних IКТ шляхом широкого їх впровадження в освітній процес ВВНЗ;

2) формувати у випускників ВВНЗ професійно важливі якості та цінності, необхідні для успішної самоактуалізації та самореалізації в інформаційному суспільстві, враховуючи сучасні вимоги до військового фахівця - офіцера, після набуття вищої військової освіти;

3) зберегти та захистити “екологію” особистості слухача, а в майбутньому і військового фахівця, оскільки інформаційне суспільство, на жаль, з одного боку, створює сприятливі умови і широкі можливості для особистісної, суб'єктної та військово-професійної самореалізації в сучасному світі, а з іншого - породжує можливості для втручання в духовний світ особи, маніпулювання ним тощо [1].

Отже, мета системи вищої військово-професійної освіти України в інформаційному суспільстві є багатофакторною і включає ієрархію цілей. Водночас головна мета полягає у підготовці слухачів, як суб'єктів навчальної діяльності, до ефективної участі у громадській і військово-професійній діяльності, оскільки “суб'єктність особи в процесі праці не може бути порушена не тільки 3 точки зору моралі чи гуманізму, а також 3 того приводу, що особа, яка сприймається як суб'єкт, ефективно вирішує професійні завдання [3;6].

В якості основних цілей можна визначити такі: 
загальне підвищення якості вищої військової освіти та надання освітніх послуг у відповідності $з$ провідними тенденціями інформації суспільства та вимог Збройних Сил України до загальної військово-професійної компетентності випускників ВВНЗ;

підвищення оборонного, кадрового та інтелектуального потенціалу країни за рахунок підготовки сучасних військових фахівців - творчих суб'єктів військово-професійної діяльності;

поліпшення ступеня доступності до вищої військової освіти для різних категорій молоді та військовослужбовців, створення для них сприятливих умов для навчання протягом життя, 3 широким застосуванням технологій, засобів і організаційних форм дистанційного навчання;

створення єдиного інформаційного простору системи вищої військової освіти та його приєднання до національної та світової інформаційної системи, без порушення вимог таємності та конфіденційності службової інформації;

інформаційна інтеграція вищої військової освіти у національну систему освіти, а також у наукову, науково-технічну, соціально-громадську i культурну інфраструктуру українського суспільства;

формування суб'єкта військово-професійної діяльності як творчого представника інформаційного суспільства, здатного i готового використовувати потенціал інформаційного суспільства для реалізації своїх посадових компетенцій $[1,3]$.

При цьому стратегічними завданнями системи вищої військової освіти в інформачійному суспільстві є такі:

наукове обгрунтування методології інформатизації системи вищої військової освіти;

забезпечення безперервності навчання, виховання, військовопрофесійної підготовки особи в системі вищої військової освіти;

підготовка військових кадрів, які спроможні до активної життєдіяльності в інформаційному суспільстві та здатні досягати поставлених особистісних, суб'єктних, військово-професійних та фахових цілей;

суттєве поліпшення якості вищої військової освіти на основі широкого й ефективного застосування сучасних і перспективних IКТ з урахуванням сучасних цивілізаційних змін, вимог сучасного поля бою, військового мистецтва та управління військами в мирний і воєнний час;

розробка комп'ютерних та інших інформаційних навчальних систем для вищої військової освіти та різних їі суб'єктів;

аналіз рівнів доцільного використання ІКТ у різних напрямах і для різних освітньо-кваліфікаційних рівнів підготовки військових фахівців тактичного, оперативно-тактичного та оперативно-стратегічного;

створення системи стандартів IКT, розробка методик сертифікації програмних і технічних засобів навчання; 
розвиток єдиної системи баз даних та інформаційних ресурсів у системі вищої військової освіти, забезпечення доцільного доступу до неї усіх категорій користувачів, суб' єктів освітнього процесу та ін.

Прикладні завдання системи вищої військової освіти України в інформаційному суспільстві наступні:

формувати інфраструктуру інформаційного суспільства в системі вищої військової освіти шляхом широкого впровадження IКТ та їх системного та комплексного застосування;

сприяти якісним змінам системних властивостей системи вищої військової освіти;

забезпечувати навчання та виховання особистості в системі вищої військової освіти 3 урахуванням тенденцій розвитку військової освіти в країнах НАТО, а також активної військово-професійної та фахової діяльності в інформаційному суспільстві [5];

упроваджувати в систему вищої військової освіти такі принципи викладання і вивчення інформаційних технологій, які мають забезпечувати формування у майбутніх військових фахівців сучасні уявлення про роль інформації та інформаційних процесів у природі, суспільстві;

інформатизувати освітній процес в системі вищої військової освіти, що $є$ важливим резервом підвищення якості підготовки майбутніх військових фахівців та боєздатності Збройних Сил України в цілому;

здійснювати підготовку технологічного військового фахівця, здатного об'єктивно сприймати та усвідомлювати процеси інформатизації сучасного життя в суспільстві, військово-професійній та фаховій діяльності;

сприяти безперервній освіті військових фахівців, забезпечувати підвищення кваліфікації, а коли потрібно і професійну перекваліфікацію, створювати сприятливі умови для навчання військовослужбовця протягом усієї активної військово-професійної діяльності;

забезпечувати формування, підтримання та постійне вдосконалення на належному рівні комп'ютерної, інформаційної та інформаційно-медіальної грамотності суб'єктів системи вищої військової освіти;

психологічно, особистісно та фахово підготувати випускника ВВНЗ до успішної реалізації військово-професійної діяльності в інформаційному суспільстві;

визначати на основі гуманістичних цінностей інформаційного суспільства такі його базові цінності, як пріоритет громадянських прав i свобод військовослужбовця, його соціальну та військово-професійну активність, ініціативність, право вибору, відповідальність тощо [1;3].

Для реалізації вищезазначених положень необхідно в організаційному, методичному, науковому та управлінському аспектах вирішити такі завдання:

організаційно-функціонально, структурно та технологічно перебудувати систему вищої військової освіти у відповідності 3 вимогами сучасного інформаційного суспільства; 
опрацювати такі методи, засоби, методики і технології оцінювання рівнів навчальних досягнень та основних видів інформаційної компетентності суб'єктів вищої військової освіти, які дають можливість, 3 одного боку, з'ясувати об'єктивний стан їх сформованості, а 3 іншого визначати певні недоліки та перспективні напрями іiі розвитку та вдосконалення;

розробити концептуальні, теоретичні і методичні основи військовопрофесійної підготовки, перепідготовки і підвищення кваліфікації різних категорій військовослужбовців в умовах інформатизації військової сфери;

обгрунтувати інформаційні методи, засоби і технології військовопрофесійної підготовки, перепідготовки і підвищення кваліфікації військових фахівців усіх освітньо-кваліфікаційних рівнів;

створити єдину комп'ютерну мережу ВВНЗ, наукових установ і органів Збройних Сил України та управління нею;

створити бази освітніх і наукових даних, забезпечити захисту і рівний доступу до ресурсів цих баз, інтегрувати їх в єдиний інформаційно-освітній простір із залученням усіх суб'єктів вищої військової освіти;

глибоко інформатизувати бібліотечну справу, в тому числі створення сучасних автоматизованих інформаційних бібліотечних систем та їх інформаційних баз, забезпечення захисту інформації і рівного доступу до сервісів цих систем і ресурсів баз [5];

створити інформаційні системи мас-медіа, що пропонують освітні i науково-популярні програми для суб' єктів вищої військової системи;

затверджувати економічні механізми і процеси господарювання, функціонування i розвитку вищої військової системи в умовах інформатизації суспільства;

створити системи статистики, включаючи унормування ключових індикаторів, що відображують стан, характер функціонування і напрями планового розвитку мережі ВВНЗ [2; 3].

Реалізація основних цілей і завдань системи вищої військової освіти України в інформаційному суспільстві сприятиме формуванню в її суб'єктів трьох видів компетентностей: а) комп'ютерної; б) інформаційної; в) інформаційно-медіальної. Це безпосередньо сприятиме підготовці військового фахівця в суспільстві глобальної інформації, формуванню здатності та готовності використовувати досягнення та потенціал інформаційного суспільства для успішної реалізації посадових компетенцій як суб'єкту військово-професійної діяльності та соціальному суб'єкту, постійному підвищенню загальноінформаційної, військово-професійної та фахової компетентності тощо.

Висновки. Якість вищої військової освіти в інформаційному суспільстві зумовлюється не лише загальною іiі інформатизацією, тобто кількістю комп'ютерів й інформаційних баз, а насамперед підготовленістю, готовністю та здатністю слухача як суб'єкта навчальної та військово-професійної діяльності до постійної та системної роботи з інформацією та ефективної їі 
переробки. У підсумку це сприятиме формування та розвитку в суб'єкта військово-професійної діяльності нових системних та об'єктивних знань щодо природи, суспільства та військово-професійної сфери, а також їх комплексного використання для вирішення завдань щодо забезпечення обороноздатності держави.

Провідні тенденції інформаційного суспільства в умовах ведення гібридної війни, суттєво змінюють традиційні уявлення про систему вищої військової освіти, яка має, по-перше, створювати оптимальні умови для набування знань, інформації та актуалізації інтелектуального потенціалу особистості в навчальній та військово-професійній діяльності; по-друге, забезпечувати комплексний та органічний розвиток слухача як суб'єкта військово-професійної діяльності; по-трете, створювати сприятливі умови для духовного, розумового, професійного та фахового збагачення кожного слухача, нарощування кадрового потенціалу Збройних Сил України як основи розвитку воєнної сфери українського суспільства насамперед в інтересах підвищення обороноздатності та національної безпеки України.

\section{ЛІТЕРАТУРА}

1. Закон України “Про вищу освіту” від 01.07.2014 р. № 1556-VII URL: http://zakon4.rada.gov.ua/laws/ show/1556-18/page2.

2. Закон України "Про основні засади розвитку інформаційного суспільства в Україні на 2007-2015 роки”. Відомості Верховної Ради Украӥни. 2007. N 12. С.102.

3. Про Національну стратегію розвитку освіти в Україні на період до 2021 року: Указ Президента України від 25 червня 2013 року № 344/2013.

4. Національна доктрина розвитку освіти. Затверджена Указом Президента України від 17 квітня 2002 р., № 347/2002. Офіційний вісник Украӥни. 2002. №16. 11 с. ст. 860. код акту 22250/2002.

5. Про Стратегію національної безпеки України. Указ Президента України від 24 вересня 2015 року 5287/2015 URL: http://zakon5.rada.gov.ua/laws/show/287/2015.

6. Стратегічний оборонний бюлетень України (Дорожня карта оборонної реформи України) / [Проект]. К., 2016. 31 с.

\section{REFERENCES}

1. The Law of Ukraine "On Higher Education" dated July 01, 2014, No. 1556-VII. (in Ukrainian).

2. The Law of Ukraine "On the Basic Principles of the Information Society Development in Ukraine for 2007-2015". Vedomosti Verkhovna Rada of Ukraine. - 2007. N 12. Article 102. (in Ukrainian).

3. On the National Strategy for the Development of Education in Ukraine for the Period up to 2021: Decree of the President of Ukraine of June 25, 2013 No. 344/2013. (in Ukrainian).

4. National Doctrine of Educational Development. Approved by Decree of the President of Ukraine of April 17, 2002, No. 347/2002. Official Gazette of Ukraine. 2002. №16. 11 s. Art. 860. act code 22250/2002. (in Ukrainian).

5. On the National Security Strategy of Ukraine. Presidential Decree of September 24, 2015 5287/2015 (in Ukrainian).

6. Strategic Defense Bulletin of Ukraine (Road Map of Defense Reform of Ukraine). [Draft]. K., 2016. - 31 p. (in Ukrainian). 


\title{
PЕЗЮМЕ
}

\author{
Василь Осьодло, \\ доктор психологических наук, профессор,
}

Татьяна Ворона

Анатолий Пелих,

кандидат наук по государственному управлению,

Национальный университет обороны Украины

имени Ивана Черняховского

\section{Высшое военное образование Украины в контексте информационного общества}

В статье проведен анализ современных тенденций в роли информационного общества в процессе подготовки личности офицера в системе выстего военного образования Украины. Раскрыты основные стратегические иели и задачи развития информационного общества в образовательной сфере Украины. Определены основные тенденции развития системы выстего военного образования Украины в условиях ведения гибридной войны. Предложены основные пути реализации прикладных задач системы выстего военного образования Украины в информационном обществе в организационной, научно-методической и управленческой плоскости.

Ключевые слова: информационное общество; высшое военное образование; качество образования; военно-профессиональная деятельность.

\section{SUMMARY}

\author{
Vasyl Osodlo, \\ Doctor of Psychology, Professor, \\ Tetyana Vorona \\ Anatolii Pelykh, \\ candidate of sciences degree in public administration \\ National Defence University of Ukraine \\ named after Ivan Chernyakhovsky
}

\section{Higher Military Education of Ukraine in the Context of Information Society}

Introduction(issue). In modern conditions, the information society represents a qualitatively new stage of sociotechnological evolution of society, which has been formed and continues to develop as a result of the leading trends of its previous socio-economic development. Such a society implies a significant and sometimes decisive increase in the role of information and knowledge in all spheres of social and human being, as well as the formation and consumption of information resources through information and communication technologies. In today's environment, the nature of the actions of these technologies is becoming global. In the developed countries of the world, the sphere of information and communication technology is the basis of the social, economic and political well-being of the population, one of the leading conditions for economic development.

Purpose of the article. Clarify the impact of the information society on the system of higher military education of Ukraine.

Research methods. In order to achieve the aim and to solve the problems, the system of theoretical research methods was used: analysis, synthesis, generalization and systematization.

Main research results. The article analyzes the current trends in the role of the information society in the process of preparing the officer's personality in the system of higher military education in Ukraine. The main strategic goals and objectives of the development of the 
information society in the educational sphere of Ukraine are disclosed. The main trends in the development of the system of higher military education of Ukraine in the conditions of hybrid warfare are identified.

Scientific novelty and practical significance of the research results. The study proposed the main ways of implementing the applied tasks of the system of higher military education of Ukraine in the information society in the organizational, scientific, methodological and management plane.

Conclusions and prospects for further research. The quality of higher military education in the information society is determined not only by its general informatization, that is, by the number of computers and information databases, but above all by the preparedness, readiness and ability of the listener as a subject of educational and military-professional activity to constant and systematic work with information and its effective processing. As a result, this will contribute to the formation and development of the subject of the military-professional activity of new systemic and objective knowledge about the nature, society and the military-professional sphere, as well as their integrated use for solving the tasks of ensuring the defence capability of the state.

Keywords: information society; higher military education; quality of education; military professional activity. 